\title{
生產的思考としての概念形成に關する研究
}

\author{
東京帝大心理學研究室
}

柴野方 彦

\section{I. 問題と方法}

【開題】“言葉は常に新しい”と言はれる。今日聞いた“花”と言ふっ言集は, 昨日聞い た“花”と言ら誩某と,いや一瞬前に聞いた“花”とも異り, 又僕の聞いた“花”と言ら 言葉と，他の人の聞いたそれとは，又異つた，夫々の場合に全く「新しい」ものとして享 け取られると云ふ意味であらら。

それは心理學的に如何に解釋されるのであろろか。一つの徵表が異つた意味を持つと言 ふのは，如何なる理由に依るのであららか。此處に我々の問題の眼目学置いて，概念形成 の構造を考察する䉆に, Willwoll に從つて, 二つの剌战語に共通な上位概念の形成の研 究を行つた。

【方法及ど手續】實驗者は被驗者に意味の異る二つの言葉を僅かの間隔(1秒—2秒) を置いて語る。それに對して被驗者は，二つの剌钱語に其通で最も近い上位概念を求める のである。この際炏の如き教示が與へられる。

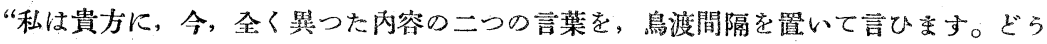

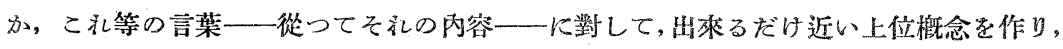
その概念を一つの表現に現はして下さい。(一つの表現と言ふのは, 或る言葉, 或は補助 語のある言葉—つまり形容詞, 副詞などのついた言葉でありまして, 定莪とか, 說明 的な交章ではありません。その時に使ふ言莱は交章語でも漢語でも英語でタ日用語でも。

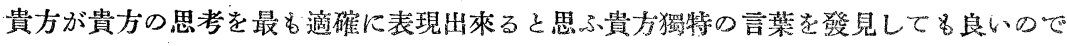
す。要は, 正磪に貴方の考へた通り表現すればい」のです。そして解答が見付かれば， 或は又, 此の場合上位概念はないと磪定したならば「よし」とか「出柬た」とか, 實驗

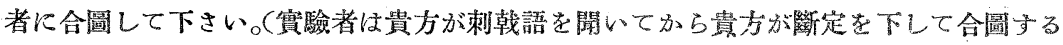
迄の時間を記錄するのですから。一然し，貴方ね，何も急いで結論を出す必要ねない のです。時間の速い僬いより，正確な記錄が大切なのです。)そして，確定した旨實驗者 に合圖すると同時に，貴方は，問題に對する答を書いて下さい。そして，引續いて，最 初の刺戟語を聞いてから，その答を確定した迄の内的の全過程を正確に詳しく記錄して

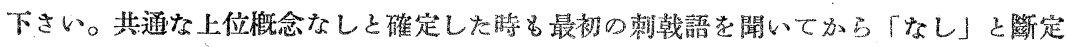
した迄の內的體驗の全過程を謷くのです。”

1) Willwoll, A. : Die Begriffsbildung. 1929. 
【刺戟語】

\begin{tabular}{|c|c|c|c|c|c|c|}
\hline 課題 & 1.人 間 & 牛 & 課題 7 . & & 赤 & 綠 \\
\hline 課題 & 2. 鳥 籠 & 犬ノ鏆 & 課題 $8 . \mathrm{a}$ & 建 & 設 & 遠 足 \\
\hline 課題 & 3. 火 山 & 憤 怒 & 課題 $8 . \mathrm{b}$ & 建 & 設 & 登 \\
\hline 課題 & 4 & 幹 & 課題 9 . & 社 & 會 & 民 \\
\hline 課題 & 5. 無條件 & 完 成 & 課題 10 . & & 會 & 雜 \\
\hline & 6. 臆病ナ & 思慮深1 & & & & \\
\hline
\end{tabular}

無意味音節を用ひずして以上の如く有意味語を用ひたのは, 要するに,「活きた」事實を 觀察したかつたのに外ならない。

又, 以上の如く，一見奇異な 1 對の語を用ひた理由は，次の Köhler の言枼に依るの である。

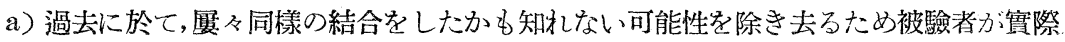
に新しい概念を形成しなければならない。その程度に困難な組合せが必要である。

b) 單語の意味が一だん廣い全體 (それぞれつ光景)の中で體制化されるやう，しかもご く自發的にさらなるのではないやらなもの一日常生活ではこれよりも, るつと容易に聯 合して來るやらな結びつきや續きは，强い自發的な體制化の例といらだけのことと思はれ る。

【被驗者】出來るだけ違つた經驗を持つた人の報告を得たいと思つた結果, 被驗者は 夫々違つた經歷と身分の人とを選しだが，僅か10人に過ぎなかつた事は色々な意味で残 念だつた。被驗者を職業別にすれば,

Vp. 1 交學士(心理學專攻)；Vp. 2, Vp. 3 學生 (法科)；Vp. 4 僵侣；Vp. 5 作 家；Vp. 6 詩人；Vp. 7 曋樂學校生徒 ; Vp. 8 女學生；Vp. 9 敎員；Vp. 10 學 生 (哲學科)

\section{II. 結 果}

A. 刺戟語の問題 先づ上位概念が形成されるか否か, 万まく形成されるか否かと言 ふ事に關聯して, 刺戟語の問題が舉げられる。即ち, 共通な上位概念が形成される第には, 二つの刺戟語が一つつ大きな全體の內で，同格化され，共通な意味內容を持つと同時に， その意味內容は差異があり, 或一定の論理的距離を持つてるなければならないのである。 而も, 此机等の條件が良け狄ば, 良い程, 形成された共通な上位概念は, 豐富な內容の「良 き」概念となるのである。

1) 佐久間檪翋： ゲシタルト心理學， 268. 
Vp. 10 課題 3 (火山, 憤怒) 85 秒, ナシ)

“....共通な上位概念々一線上にある二つの言葉の間に形成されるのである。”

$V p=9$ 課題 3 (前同)(93 秒, ナシ)

“....川は物であり, 憤怒は精神作用で, 違つた土臺の上に立つてるるのだと考へ“ナイ” と云ふ答觉確かにした。”

二つの刺戟語が一つの大きな全體の內で，同格化され共通な意味內容を持つと同時に， その意味內容に一定の距離がなければならぬと言ら事は, 刺戟語そのもの〉布置に依る事 勿論であるが，又，それは，必然的に被驗者の文脈の位相性に低るのである。つまり，同 一の制械語に同一の反應, 同一つ意味內容の「享け取り方」などと言ふ事は事實無いので ある。刺戙語は, 各被驗者に依り, 夫々, 不知不識の內に何等かの性質の類型の內に分類 され，その解釋の仕方に從つて上位概念は形成されてるるのでする。

Vp. 6 課題 2(鳥籠, 犬の鎻)(19 秒, 束縛物)

“...絬局, 兩者は生き物を束絤するものだと言ふ概念に氣がついた。...”

此の場合「物の語の對」である刺戟語を作業（目的）穖能の素地に於て取り，それに應 處した共通な上位概念を形成したので女る。同樣に, 材料, 活動原因, 本質(範疇), 特性 等の類型に於て,「享け取られる」のである。

B. 思考の地盤 之等の「享け取られ方」の如何が，被驗者の思老を決定し，一定の 態度を取らし，方向を「態づくり」, 思考の地盤 (Denksituation) とでも言らべき形態を 思考の素地として形成するのである。刺戟語が上手く上記の思考の地盤を「態づくる」か 否かに依つて, 概念の形成が出來るか, 或はその形成に要する過程が複雜か容易かが左右 されるのである。

此の思考つ地盤は我々の報告に於ては, その形成過程より大別して次の二つに分類され る。

1) 二つの刺戟語の解釋と共に, 求める上位概念に對して, より一般的な內容の思考の形 態力゙體制化される場合。

2) 刺戟語の內, 何れか一方の解釋と共に體制化された思考形態の內に, 他の刺戟語の解 釋と共に體制化されたものを包括する場合。

第一の場合は, その機能的な形成過程に依り, 更に, 次の三つに分類される。

1a）殆えど無意識に，直觀的に刺戟語の分析を行ひ思考の地盤を形成するもの。

1b)二つの刺钱語と共に體制化される思考の地盤の內, 第二のものは, 刺钱語の矛盾葛 藤的分析 (Konfliktanalyse) に体り形成されるもの。

1c）以上の他に，我々は，目的分析 (Zielanalyse) に依つて思考の地盤を「態づくる」 
むのが考へられる。

斯樣な渦程の事態に應じて形成された思考の地盤は, 決して固定的なるのではない。そ れは，可動的であり，機能的であり，概念形成の全過程に於て，他の部分と共に相屬して 規定されるものである。

此の思考の地盤から更に上位概念の形成への過程を取るのであるが，それ等の契機ば， 思考の地盤そのるの〉機能的な結構に低る甘のと言へるのである。思考の地盤は，それ自 身「態づくられた」むのではあるが，そこには，成可り「ゆとり」があり，可用性（Disponibilität) 或は可動性 (Lockerheit) があり, それをを契機として, 上位概念の形成過程 が相屬するのであるが，その過程は，その態度に依り次の二つに分類される。

1) 思考の地盤を契機として推論的に骨折つて上位概念を形成するもの。此の場合, 論理 的整理, 推理, 半断听が相屬する。

2）思考の地盤の可用性学契機として直觀的，飛躍的に上位概念を形成するもの。

思考の地盤が自發的なものを持つて居り，可用性があると言ふ事は，それ自身一つの形 態として完成してるず, 未成態 (Vorgestalt) でる䉆, その形態完成 (Ergänzung) を 目指するのであると考へられる。其所に，可用性の力问を指すものが現はれ，思考の地盤 は素地として背後へ鲜礼る。

Vp. 8 課題 6 (臆痛な, 思慮喍い)(15 秒、なし)

“....「思慮深い」人之「臆病な」人と云ふことを别々に考へ, こ5云ふ考へをつきつめ て行けばい〉のではなかららかと思びしたが，....”

C. 㓊象方向を指し示すものは，時には，「何かごちやごちやしたもの」,「ぼんやり した」もので, プログラム的, スケッチ的なるのでまつて, 解答の瑔知として輪敦的に 解答の領域をも示すのである。これは, Duncker の使つた意味を獚く解釋しての矠象 (Signalement ; Suchmodell) と言へるのである。

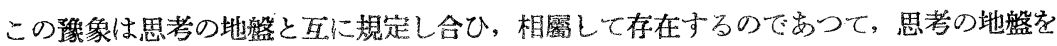
素地とすれば, 预象は團柄である。

第一の穆象が，その場合の思考の地盤に低り不適當とされた場合は，そ机は破壤され、 て，新しい第二の妤象が生じ，同時に，新しい思考の地篮が「態づくられる」のであ

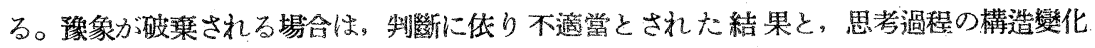
(Umstrukturierung) に俄るのとの三つの場合がある。

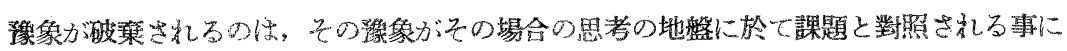

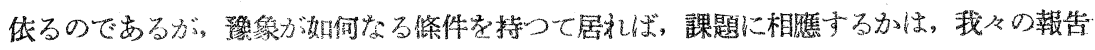
1) Duncker, K. : Zur Paychologie des produktiven Denkens. 1935, 91. 
では残念乍ら知り得ない。

D. 推理, 判斷, 抽象 我々の課題の呈出の仕方が, 本來, 生產的思考としての, 二 つの刺戟語に共通せる上位概念の形成を問題としてるる第, 必然的に其處に, 所謂, 思惟 的なものとして, 推理, 制斷, 抽象が見られるのは當然のことである。只, それ等の, 推 理，籼斷，抽象は概念形成の全過程の內に，全く獨立したものとして存在するのではなく， 課題に, 或は形成概念の豫集に應處してて, 概念形成特有のものとして, 規定され, 相屬し て分節肢として含まれるものである。

その內,「抽象」は概念形成渦程中に於て, 最も重要な役割をなすもので（概念は抽象に より得られると考へら品てるた事を考虑してを分る), 推理も制斷も, この「抽象」に相屬 したものとして機能的に現象するのである。然しこの場合の「抽象」と言ふのは，單に 對象から共通性質を「抽き出し」共通でない性質を「捨去る」と言引意味ではない。心理 的に言つて，左樣な意味での「抽象」と言ふものはあり得ないと言ふことは，既にWertheimer, Duncker 等の說く所である。

Vp. 2 課題 3 (火山, 憤怒)(50. 秒,なし)

“火山と聞いて爆發を聯想した。㥽怒と聞いた時, 火山の爆發から,憤怒の爆發を考へた。 雨者は “爆發” と言ふ共通な言葉を持つてみると思つた。然し直ぐ火山の爆發と, 憤怒 の爆發は, 爆弦と言ふ交字面と, 言葉の昔は同じだが, 全く性質の違つたものだと考へ た。本質的に兩者は異るものと思ひ, 他の方面も一寸考へて見たが, 邀に無しと結諭し た。”

このVp. 2 は “火山”と聞いて “爆發” 丞聯想した䉆, その事態に應じて, “憤怒”と 聞いた時も，直ぐ,“憤怒の爆發”と云ふ事を考へたのである。只，單獨に“憤怒”を聞い、 たとすれば、“爆發”、は必ずしも浮ばなかつたもか知れない。憤怒”を"爆發”の象面に於 てとらへた所に，抽象作用の指向性を見るのである。抽象作用の先づ第一步は, 事態一 即ち, 課題とか, 被驗者の文脈, 棈え等を含めて一一から要求される指向性に從つて, 對象を分析解釋するのである。そこに思考の地艋が形成され, 爆發” が豫象として浮び上 つた。がっ“然し”と“直ぐ”此の被驗者は考へたのである。火山の爆發”と憤怒の“爆發”

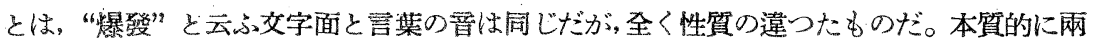
者は異るものと思ひ....”と! “火山”に低り規定され，それに相屬した“爆發”は“憤怒” に相屬した“爆發”と，明確に區別され兩者は本筫的に異るものとさへ斷定されてるる のである。
1) Dunker, K. : a. a. O., 95.
2）中村克己：ゲシタルト學說に於ける論理學の問題 第1部 107 .
3) Duncker, K. : a. a. O., 57. 
$\mathrm{a}(\mathrm{P})$ と $(\mathrm{Q})$ は個々に幾らつきつめても共通性質は見出されなないのである。同樣な報告 ガある。

Vp. 2 課題 7 (赤, 綠)(さ4 秒, なし)

赤と聞いた時, “色”と考へ，綠と聞いた時之も色だと考一た。で，上位概念は「色」に しょらと思つたが，然し色は「色」だが,「赤い色」と「綠色」とは異ると云ふ反省があ つた。同時に「赤「綠」の特性を離㡆て「色一般」は考へらて奴と思ひ之等の上位概念 は奥いと斷定した。”

Vp. 10 課題 (前同)(110秒,なし)

“乣しても圖形が浮んだ。「赤」と聞いた時，ちらと「赤熱」と言ふ言葉が浮びかけたが 同時にE大な，非常に鿇度の小さい鈗角三角形が額の前から前方に延びる感じがして・.

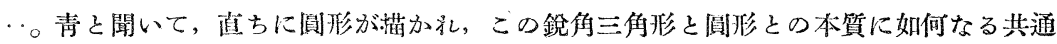
なものがあるか見極めようとしたが，長い間，その圖形が對立して，ぞらしても解決を 得ら却なかつた。

然るに上記の課題に於ても, 他の多くの被驗者は, 共通な上位概念として“爆發” 或は “火”,“色”㦛げてるるのである。

Vp. 4 課題 3 (火山, 憤怒) ( 34 秒, 爆發)

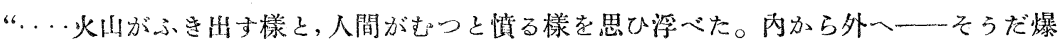
發だ。"

此處では“爆發”、の意味の限定が「何物かに」消されて—と言ふよりも寧ろ, その文 脈の位相性による意味に「何物か」が加はつて，“爆發”は元の意味とは異つた事態での意 味を獲得して，共通な上位概念を組みたてたのである。それは，只，固定した意味での「抽 象」一共通性質を抽き出し，異質を捨て去る一一で得られたものを，材料として，その場 の事態に應じたやり方で，新しいものを組みたてたものである。活きた」意味での「抽象」 は，本來，か子るものであつて，そ狆は推論的なものであると考入られる。我々に於て問 題となるのは，「抽象」ではなくしてDuncker の言ふ綜合的集聚 (synthetische Ablesbarkeit)である。

之等を明確にする鹂に次の圖式が考へられる。即ち, 今, 假に一つの對象を $\mathrm{P}(\mathrm{a}, \mathrm{b}, \mathrm{c} \cdots)$ とし，他を $\mathrm{Q}(\mathrm{a}, \mathrm{m}, \mathrm{n} \cdots \cdot$...) とすれい゙゙，固定的な意味での「抽象」に依り出された共通なもの を|a|とするのであるが, 我々は, か子る|a|は此の場合, 考へられないのである。そ れは (a) $\mathrm{P}(\mathrm{b}, \mathrm{c} \cdots)$ であり，(a) $\mathrm{Q}(\mathrm{m}, \mathrm{n}, \cdots)$ であつて, Vp. 2 の言ふ如く異るものである。 然るに, 我々は日常的に,「活きた」ものとして, 上位概念を形成寸るのは, か小る事態に 於ては我々は淔ちに，(a) $\mathrm{P}$ と（a) Q の相屬から $\mathrm{a}(\mathrm{PQ})$ と云ふ新しいるのを生產する 事に依るのである。

斯樣な新しい事態の突然の形成は，一般的思考の場合の構造變化の一として考へられる 
のである。

\section{E. 構造變化}

Vp. 1 課題 10 (社會, 民族)(16 秒, 人間の集り)

“これは難しい問題だと思つた。不安と同時に非常に緊張した。…壟會」と「人間」と は切りはなせ㰠と云ふ言葉の關係から「社會」から「人間」と云ふ Begriff をむつて來 た。そ礼から民族に引きあてて考へて見ると，民族は社會の更により集つたものだと云

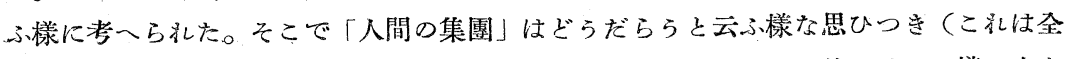
く思ひつきだつた。その間の意識と感情のたゆたいがあつた。から前に言つた漛に之を prüfen して見て滿足したので夫にきめてほつとした。”

上位概念の形成, 即ち我々の場合では, 課題の二肢による渘象の課題に適應する々のと てての形態完成は, 思考形態の構造變化により, 突然性 (suddenness) を持つてもたらさ れるのである。效果的な構造變化に依り, 此の形態完成は, 急速に, Duncker の言某に体 れば, 自發的 (wie von selbst) に行はれるのである。それと共に緊張狀態は飽和し, 弛 緩の感情, “出來た”と云ら滿足感, “濟んだ”と云ぶつとした感じと共にそれ迄の混亂狀 態は秩序ある狀態に一轉するのである。

斯樣な構造變化の象面及び概念形成過程の指向性の機能的な, 內的なものとして, 我々 は矢張り, 綜合的洞察 (synthetische Einsicht) の存在と機能とを,どの被驗者の報告に も認め得る事が出來るのである。

F.心像 概念形成に於ける直觀的諸要因の內の重要なるのとして,心像があげられる。 その內我々の報告に於ては, 次の三つが問題とされる。郎ち, 事物心像, 象徵的心像（圖 式）並びに言語心像である。

\section{【事物心像】}

Vp. 6 課題 3(火山, 憤怒)(8 秒, 爆發物)

“....火山からは然え上る激しい火の手を眼にはつきりと心地よく思ひ浮へたた”

Vp. 7 課題 4 (花, 幹)(370 秒, 植物體の一部)

“花では先づ强く黃色の五辨の花を思ひ.....”

被驗者は, 總て, 多少とも直觀的物的心像を浮べてるるのである。

事物心像に於ては, その場に於ける一見無線と思はれる樣な子のは, 我々の報告に於て は、二つしかなかつた。而も，それは，同一被驗者に於てであつた。

Vp. 7 課題 5 (無條件, 完成) (135 秒,なし)

“無條件では, 譯もなく, 或港の稅關の建物でもある樣な波止場と船とを思ひ浮へた。 自分でも不思議に思って考へた。戰時なので陸兵など輸揆してるるのだららと思つた・ . 。”,

1) Duncker, K.: a. a. O., 44. 
而も, 此等の一見無緣と思はれそ事物心像は第一の刺戟語と共に形成されてて, 概念形成 の正罍な發展に阻止的な役割をなすのである。

Vp. 7 課題 6 (臆病な, 思慮深い)(40 秒，なし)

“臆病なと言はれて 同時に蛇を想び浮べいやだを思つた途端，思虑深いと言はれたの で，何故か，知慧があると感違ひして，アダムもイヴのエデンの蛇はどうだろらと思つ

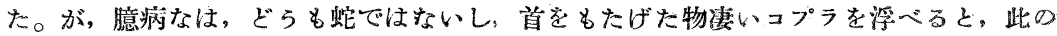
考一は駄目だと思つた。思慮深いと云ふ言葉の裹に，黑い銳い影が，チラッと胸に浮ん だがそそが智慧なんだと矢張り智慧にこだはつた。此の間ずつと蛇を想ひ浮べいゅな 氣持が考一の發展を邪魔しつづけてるた....”

「臆病な」と言ふ刺戟語と共に形成さ礼た「蛇」の事物心像は, 非常に明瞭, 且, 强力な 鳳, 第二の刺戟語を「感違ひ」させたのみか, 最後迄, 概念形成の正當な渦程を阻止しつ ら゙けたのである。

斯樣な一見無緣な事物心像が，果して課題の艾配に低らない偶然的心像に還元せられる ものか，或は，何等かの意味を持つか否かは我々の場合では判明しない。

又, 概念形成過程に於て, 多くの場合, 第一の刺㦸語と共に形成された事物し像は非常 に强い位置を占めるのである。而して，第一の刺戟語と其に形成された事物心像と第二の 刺戟語との質が相反する場合には“招や”とが意外”だとが“不愉快”或は“そぐはぬ” と言ら風な種類の內語すら件つて僢時, 概念形成の夙滿な發展空阻害寸るのでるる。又, 第二の刺戟語により形成され九た事物心像力゙第一の剌戟語により形成された事物心像と何ら かの內容連關がある場合には，并の心像の結合は極めて滑らかに行き，多くの場合，第一 の事物心像か第二の事物心像老包攝してしまらのである。此の場合にも, 構造變化方滄造 的な役割をなす事は勿論である。

【象徵的圖式的心像】

Vp. 10 課題 $8 \mathrm{~b}$ (建設, 登山)(15 秒, 努力)

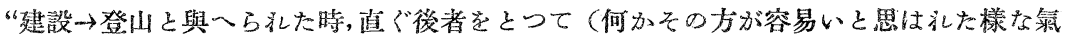

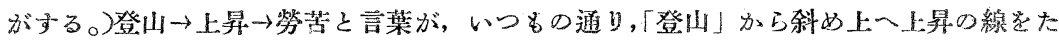
ぞつて次々と出て來て, 最後に「努力」と出て來て「建設」と「登山」を底邊とした正 三解形圖式の頂點が出來, 安心した感じで「ょし」を㝘つた。”

此のVp.10に於ては, 言語は思考圆式に沿つて墢展するのである。圖式がその自體の自 足性に從つて墢展するを共に，思考の線が發展して，圖式は竟に概念を象徵するに至るの である。彼に於ては，圖式が主として，光礼に沿つて內語か酒置されて行つたのである。

然し，事物心像男全然浮ばないのではない。

Vp. 10 課題 $8 \mathrm{a}$ (建設, 遠足)(20秒, 直線)

“建設と第一の刺戟語が與いられた途端のありりこ巨大なクレーンが動いてるるピルデ 
ィングの基礎工事場が强烈に頭の中に描がた。思考の線は垂淔に上昇した。第二の刺 戟語が與へられたが暫く，その上昇の線の後を追つてみた樣だつた。そしてハッとして 第二の刺戟語は「遠足」だつたなと浮んだ。すると同時に, こ壮は水本だと思つて, 始 めの垂直の線の止昨をさまたげる奴だと下检快に思つた。暫くそこにこだはつてるたが， どらも解決が見出されなかつた。始めの垂直の線の前進を續けたがつてるた樣だつた。 不愉快なま〉直線とした。”

事物心像はありありを“强烈に頭の中に描かれた”が「思考の線」の活動と共にそれは， 全く、後退してしまつたのであつた。

圖式は以上の如く, 全く象徵的に, 純粹に, 强く主知化されて現象するとは限らないの であつて, 事物心像, 或は, 言語像の中間にあり, 象徵的圖式への現象的な過渡的心像と 考へられるものもある。而して象徵的圖式的心像は, 他の心像同樣, 阻害的な役割孛な寸 ものもあるし鄉導的役割をなすものもまる。「思考の線」の圖式的心像が如何なる役割をな すかは次の報告が示してるる。

Vp. 10 課題 6 (臆病な, 深慮深い)(140 秒,なし)

“...圖式が浮ばないので不安である。圖式は僕の思考に於ては依りかつる椅子の樣な ものだ...."

【言語心像】屚々思考と言語の展開が，有機體の成長に於ける型と內容の如く密接に 本行して織りなされるのである。

Vp. 2 課題 7 (赤, 綠)(4 秒, 色)

“赤と聞い時, 色と浮び, 綠と聞いた時も同樣, 色と言ふ言葉が浮んだ。”

又, 思考內容が完全に意識に成熟して來ず，未だ充分形態化してるないのに，全體的な 交胍に依つて, 言語心像が形態化する場合がある。

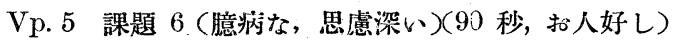

“直ちに「打人好し」と言ふ言葉が浮ぶ。後はその說明的な內容を考へてなた樣である。 郎ち, その過程は…‥”

而して此の場合の最初の言葉は，その荷ふ意味が豐富であると否とに拘らず，必然的に それを中心として結晶化が行はれ，力動的な形態化が行はれるのである。即ち、此の場合， 最初の言葉は, 思考形熊を引き出寸爲の, 恰も, 圆書館の圖書番號カードの如き役割をな すのである。然し，それが，必ずしも，正しい概念形成の方向へ向くとは限らず,却つて， 阻害的な役割をなしてるる場合もある。

更に言語形成のない概念形成を擧げることが出來る。概念力澺識では全く明析でありな がら被䮰者は長い間, それを言㷊に表現する事が出來ないことがある。

Vp. 8 課題 2 (鳥籠, 犬の鎻)(40秒,なし)

(此の被驗者としては一番長い反應時間である。) 


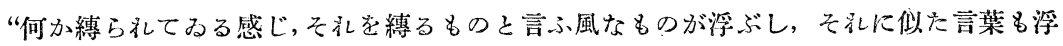
ぶけ叔ども私の思つてるることをその債表はせません。”

Vp. 5 課題 2 (前同)(55 秒,なし)

“人間々動物との或る關係。說明す汭，人間が動物を（家庭動物として）束縳するある 手段。然しこ汅には家庭的な (Domestic と云ふ言葉浮ぶ) 愛が加はつてるる。適當な 表現語見付らず。”

多くの交胍が交錯した位相に於け方㡤象心對した場合に, 對象定正確に知れれば知る程, 言語的な概念が形成されないと云ふ事實がある。郎ち言語形成のない概念形成があると云 ふ事, 更に換言すれば, 概念形成に於ては言語形成が必ずしも第一義的なものでないと云 ふ事が言へるのである。概念侍時としてその場の文脈の不可表現性の爲, 言語表象の體制 化を待たずして分凝するのである。思考の成熟が言語的なものに先立つ傾向があると言ふ 事は Selz \& Simoneit \&明らかに主張する所である。

穊念形成に於ける心像の機能を要約寸玌ばそれは思考形態を明膫ならしめ, 支へる役割 安するのであり，剌戟語の意味の明白な把握と目的概念に導く場合に於ては促進的な役割 をなすのである。

G. 人性的文胍概念形成に於ては, 飽く迄, 課題による外的條件の規制を受けて, 內的條件としての, 個人の先天的素質や, 後天的に生じた傾向, 過去の經驗, 環境, 職業, 日常性等による影響と「構え」が極めて重要な機能的位置を持つてるる。先天的素質とし ては，所謂「體質的傾性」等が擧げられるが，これらも精神的方面の類型たる，「直觀型」 「思考型」，或ひは「分析型」「綜合型」等の特性と同樣に，思考の過程こっでは概念形成の過 程に何等かの影響を及ぼすものであると考へられる。過去經驗, 環境の影響, 職業, 日常 の生活態度等は一見概念形成の本質的なものとさして梁い聯關もるものとは考へられない であららが, 然し, 我々の報告は, 之等のものが決定的に重要なるのであり, 指向的なも のである事宗してるる。

Vp. 3 課題 5 (無條件, 完成) (75 秒，なし)

“民法で「條件」と「期限」の問題を一纒めにして同じ項目で習つた故か「期限」と云ふ 言葉が浮び「期限」と「完成」ならば關係があると考へたが,「無條件」と云ふ言葉では ぞうも解答が導き出せず, 最後迄「期限」と云ふ言葉が出て, 共通な上位概念は出來な かつた。"

Vp. 7 課題 7 (赤, 綠) (100 秒, 色彩)

“....僢間ベートーベンの熱情ソナタの第一樂章がありありと聞えた。が,別にそれを發

1) Selz, O.: Zur Psychologie des produktiven Denkens und des Irrtums. 1922. 308,318 .

2) Simoneit, M. : Beiträge zur Psychologie des Denkens. Das schaffende Denken. Arch. Ges. Psychol., 55(1926). 
展させはしなかつた。赤い色から此のソナタを思つたやらだ。…”

Vp.7は豆樂學校の生徒である。即ち, 日常性, 生活熊度と云ふ心のは,「法科生」は「法 科生」らしい考へ方をし,「音樂生」は「晋樂生」らしい考へ方をすると言ら簡單な言葉で あらはされるのであるが，此等は，全く概念形成過程には，決定的なむのである。

而も, か〉る內的條件は, 決して烏合的に渾沌として, 偶發的に自由に出て來たもので はなくて，飽迄，課問の框に依つて一定の方向に方向付けられ，課問と解決，その場にふ さはしいやうに，それ自身，有意味に「態づくられ」て現出するのである。從つて，勿論 概念形成に於ては，課問に應處する思考形態の體制化こそ第一義のものでるるが，その根 本に, 必然, 不可缺的に此の「態づくられ」て現出する內的條件が, 全體的に能動的に存 在するのである。その意味で，之等の內的條件なるものは，力動的に統態として機能的に 働くのでもつて, 此を「人性的文脈」と總稱出來るのである。構え」或は「精神的調整」 なるものは此の「人性的交脈」の一つの位相に於ける屬性であると考へられる。

H. 意志及び感情 概念形成過程に於ては, 又, 本質必然的な分肢として, 意志が洞察 の方向性と相互に相規定し合ふものとして現れし，構造變化の場合に重要な機能的役割をな すのである。又, その場合, 感情が意志に依存して, 矢張り, 概念形成過程の本質必然的 な一分肢として働くのである。

I. 形成された概念＼cjkstart形成された睤念は,一つのまとまつたものとして現前するのであ る。被驗者の心的素地の上に，他のものとはかけ離れて，明睹に凝集されたものである。 その概念を形成する迄の渦程とは,「跳び離れてて光に照らされた樣に」明らかに，雕刻的 なものとして現はれるのである゚“....索得て滿足した。”....に安定した。と云ら滿足感 を件つて，心的素地に一つの形態として分凝するのである。その得られた概念は，刺戟語 の何れにも含まれてるない全く新しいものである。假令, 同じ言葉であつても, 全く, 違 つた，新しい質のものとして，刺戟語が與へた事態に應じてと,その場の事態に要求されて, 新たに生產された分凝態である。

形成された概念は，安定感を伴ふものは，「良い概念」であり，不滿感の件ふものは「惡 い概念」である。此の「良い」概念は又,「豐富な內容」を持つた概念であり,「惡い」概念 は「貧弱」な內容の概念である。然し，豐富な內容の概念とは，その形成過程が種々な變 化に富み，或は諸心像が豐富にあり,「貧弱な」內容の概念は，その反對であるとは，必ず しも言へないのである。

1) 此の場合の意志とは, 主觀の文脈の位相性を根柢として, 對象に對し,ょり继實な(論 理的眞實よりも現實的, 或は言はば, 客觀性よりも主觀的普遍と言つたもの）兒事態 性を與へようとする意志一。 
「良い」概念と「惡い」概念との規定を擧げると次の樣になる。a)「良い」概念は, 或 特定の心像を中心として, 心像が一定の秩序を形成して居り, それは, 緊密感と安定感に 伴はれてるる。現實的機能的に規定されると共に可塑性を持つてるる。b)「惡い小概念は， 次の二つに分けられる。i）所謂「もやもや」として, 明䀢でなく, 刎論, 安定せず, 確信 の件はれないもの。ii）徵表が並列的で互に獨立性を持ち中心となるものがないもの。つ まり，强く分凝しないもの。

\section{III. 概 括 的 結 論}

以上を概念形成の過程に從つて概論的に總括すれば次の如くなる。

1. 刺戟語は,「良い刺戟語」でなければならない。「良い」刺戟語は事態を形成して，その 事態に於て要求される役割家持つた內容のみを，その「意味」として現前する。

2. 刺稀語が解釋されると同時に,そこに思考の地盤とでも言ら可き思考形態が形成され， 同時に，相屬してそれを素地とした圖柄とでも言ふ可き「豫象」が體制化される。 此の「豫象」は課題解決のプログラム的, スケッチ的なものと指向的なものである。

3. 思考の地盤は Koffka の言ふが如き空隙 (Rücke)のある思考形態であつて, 上:「妤 象」の指向性に相屬して, それ自身の自足性に從ひ形態完成を行ら。そ。形態完成の過程 に於て，概念形成獨特の，而马その過程に規制された推理，刵断，「活きた」意味での綜 合的集聚が行はれるが，杂等よりも一層大切なのは思考形態の「構浩變化」である。此 の「構造變化」は對象に對して創造的に活動するのである。

4. 此の「構造變化」に依り「豫象」は思考の地盤の中に形態化されて, 同時に, そ就 迄の「豫象」とは全く違つた,「新しい」概念が形成されるのである。從つて概念が形成さ れないのは課題の性質に体るか，からる「構造變化」が行はれない爲である。

5. 以上の如き全過程を通じて，綜合的洞察は大いなる機能的役割をなしてるる。

6. 之等の概念形成過程中の心像は, 主として, 思考形態を明䐲ならしめ, 響導し, 支へ, 目的概念へ導く場合に於て促進的な役割をなすのである。

7. 生產的思考としての概念は以上の如き過程を經て形成されるものと考へられるのであ るが, 勿論, すべて皆, かつる過程を殘らず通ると云ふのではない。思考の地盤が形成さ れるやいなや直觀的に概念を形成するのも多いのである。

(1938 年 6 月 29 日原稿受附)

1) 敎示に於て“....貴方の創作した言葉でもよい一貴方の形成した穊念を正しく現は せると思へば…””之云ふ事を言つたにもか〉はらず, 形成された概念は，皆，經驗 に根ざした現實的なものであつた。 
(From the Psychological Institute, Tokyo Imperial University).

\section{The Concept-formation as Productive Thinking}

by

\section{Masahiko Sibano}

What does it mean from a psychological point of view, that one word has many different meanings? In order to know this function, I made a kind of simple experimental study about the concept-formation. According to A. Willwoll's method, I gave subjects a strange couple of words as stimulus, and made them form a superordinate concept common to these two words. Then I asked the subjects to give reports on their experiences durng the process of concept-formation.

As the results of this experiment, I am sure that the process of concept-formation is explained as follows: When a stimulus, which is adequate, is given, a certain thought-situation is formed according to the present total situation. At the same time a "Signalement", which may be called "Figur" on this basic. thought-situation, is composed, and this Signalement has three directions, viz. direction of sketch, of programme, and of intention. On the other hand, thoughtsituation is moveable and it makes its own completion entirely in proportion to Signalement's intention.

In the meantime, reasoning, judgement, and abstraction, which are involved in the process of concept-formation, are performed in mutual dependence. For example, the abstraction does not mean to draw out only the common (a) from $\mathrm{P}(\mathrm{a}, \mathrm{b}, \mathrm{c} \ldots . .$.$) and \mathrm{Q}(\mathrm{a}, \mathrm{m}, \mathrm{n} . . .$.$) and cast away: others as unnecessary. When$ (a) $\mathrm{P}$ and (a) $\mathrm{Q}$ are taken from original $\mathrm{P}$ and $\mathrm{Q}$, immediately a new concept (a) $\mathrm{PQ}$ is formed. This process may be contained in "Umstrukturierung" in a broad sense.

Three kinds of images were reported in this experiment, viz. the image of things, symbolical diagramatic images and verbal images. They are not always essential to concept-formation, but as far as they support and realize thought-configuration, they are useful. Emotion and will appear as essential and inevitable factors in the process of concept-formation. Will works as the intention in the process and emotion too, as far as it cooperates with will, does the same. However, more powerful as determining conditions on the concept-formation are subjects' inherent and acquired characters, circumstances, and worldliness of their lives. They operate as a unity and may be called the human context. The concept is generally formed in this way, but not every concept passes through this course. Some of them are formed at the same time when the thoughtsituation is formed. 